\title{
OBSTACLES AND FACILITATIVE OPPORTUNITIES WHILE STUDYING SOCIAL WORK WITHIN AN OPEN AND DISTANCE LEARNING CONTEXT
}

\section{Petro Botha}

\section{INTRODUCTION}

The current number of registered social workers in South Africa is insufficient to meet the demands of the national welfare system (Earle, 2008:150). Earle (2008:49-58) bases this statement on various factors and estimations. In 2005 the vacancy rates within the Department of Social Development were on average $37.9 \%$. Because of the salary differential between the public and private welfare sector, it is likely that the vacancy rate within the NGO sector is even higher. Based on the estimated population growth between 2005 and 2015 and the annual requirements for social workers, calculated at the current ratio of 23.6 social workers per 100000 of the population, an additional 468 social workers will be needed by 2015 . Vacancies created by retirement, death, emigration, social workers taking employment opportunities outside of social work, and voluntary exit from the labour market because of family responsibilities also need to be taken into account. An estimated total of 3970 new social workers will be needed by 2015 to fill these vacancies. Calculations also need to take into account the government's norms and standards regarding social worker-to-population ratios translated into numbers of social workers per 100000 of the population; these norms are roughly 20 (urban), 22 (peri-urban) and 33 (rural). If these norms are implemented, the current shortfall of social workers employed in welfare is 7631 . More social workers will also be needed to implement governmental programmes or legislation. Barberton (in Earle, 2008:54) estimates that 67507 social workers will be needed in 2010/2011 to fulfil the requirements of the Children's Act (38 of 2005). Although these estimations are fragmented and incomplete and do not add up to a clear total, they do convey the point that the demand for social workers in South Africa is considerably higher than the current numbers available within the labour market (Earle, 2008:58).

The supply of social workers in South Africa is dependent on the throughput of 15 tertiary institutions providing social work training, namely the universities of Johannesburg (UJ), Stellenbosch (US), Fort Hare, North West (UNW), Free State (UFS), Cape Town (UCT), Western Cape (UWC), Pretoria (UP), KwaZulu-Natal (UKZN), Limpopo (UL), Venda (UnuVen), Witwatersrand (Wits), Nelson Mandela Metropolitan (NMMU), Zululand, Huguenot College and University of South Africa (Unisa) (Earle, 2008:58). Since 2007 all student social workers have to complete the degree of Bachelor in Social Work (BSW), a fouryear degree culminating in a postgraduate qualification registered with the National Qualifications Framework (NQF) (Lawlor, 2008:37). In order to meet the demand for social workers the throughput of student social workers from tertiary institutions need to be increased.

\section{THROUGHPUT OF SOCIAL WORK STUDENTS AT SOUTH AFRICAN UNIVERSITIES}

Student throughput or retention is often viewed as a measure of the percentage of students who gain a course credit or an award based on the number of students who registered for the course. According to Ashby (2004:66-72), this is a narrow definition of the concept and only refers to the institutional dimension, while the student and employer dimensions also need to be taken 
into account. The institutional dimension refers to indicators that an institution uses to assess its own performance and refers to academic progress. The student dimension includes students' learning goals and experiences. Some students may achieve their learning goals by completing only one module or by studying material without sitting for an exam. The employer dimension refers to the "employability" of the students. This dimension is measured by how soon students are employed after completion of their studies as well as by the feedback received from relevant employers. Comparisons between the throughput rates of different institutions need to take into account the definitions used to measure throughput or retention rates. Factors such as different institutional entry policies and differences in student profiles also need to be considered (Ashby, 2004:70). Other factors also need to be taken into account, e.g. that a subject such as Social Work is available as an elective for students registered for other undergraduate degrees, and that student social workers may not register for Social Work for a year or more (Earle, 2008:100). In the National Plan for Higher Education, the South African Department of Education (Earle, 2008:99) proposes throughput calculations using the annual number of graduates from a programme and the total number of students enrolled within the programme. This thus refers to the institutional dimension of throughput. Schenck (2008:5) applied this calculation to the data provided by Earle (2008) to compare the throughput of student social workers at South African universities (Table 1).

TABLE 1

THROUGHPUT OF SOCIAL WORK STUDENTS AT SOUTH AFRICAN UNIVERSITIES

\begin{tabular}{|l|c|c|c|}
\hline & Registration 2001 & Final 2004 & $\%$ \\
\hline University of JHB & 75 & 17 & 22 \\
\hline University of Stellenbosch & 85 & 19 & 23 \\
\hline Fort Hare Alice & 180 & 47 & 26 \\
\hline Fort Hare EL & 33 & 8 & 24 \\
\hline University of North West & 25 & 5 & 20 \\
\hline University of Free State & 34 & 13 & 38 \\
\hline Huguenot College & 86 & 41 & 48 \\
\hline UCT & 58 & 38 & 66 \\
\hline Walter Sisulu & 92 & 21 & 23 \\
\hline UWC & 112 & 77 & 69 \\
\hline University of Pretoria & 30 & 19 & 63 \\
\hline Unisa & 999 & 72 & 7.2 \\
Unisa overall (2006) & 227539 (head count) & & $6.1 \%$ graduated \\
\hline UKZN & 127 & 13 & 10 \\
\hline University of Limpopo & 43 & 38 & 33 \\
\hline WITS & 42 & 14 & 52 \\
\hline University of Venda & 100 & 52 & \\
\hline
\end{tabular}


Taking into account that this comparison does have many limitations, because of the factors mentioned above, it does give some indication of the throughput rate of student social workers at various universities. The Table indicates that Unisa has the highest intake number but the lowest throughput percentage. It also indicates that the throughput of the Unisa Department of Social Work is in line with the rest of Unisa. As an open and distance-learning (ODL) institution, Unisa increases access to education for people who do not have the opportunity to study full time, who are living in remote areas, and who could not afford the fees of other universities (Qakisa-Makoe, 2005:45). Within Unisa access to education for black students has increased significantly since 1994 and the proportion of black students rose from $55.3 \%$ in 2004 to $64.05 \%$ in 2008 (Unisa, 2008:18). However, more and more concerns have been expressed regarding the lack of student throughput at Unisa (Principal, 2006:5). In 2008 the Unisa Throughput Forum instructed a task team to develop a conceptual model indicating factors impacting on student throughput at Unisa. This model will inform the development of a tracking system which will allow Unisa to fulfil its 2015 objective of providing effective and appropriate student support (Prinsloo, 2009:7).

\section{FACTORS INFLUENCING THROUGHPUT OF STUDENTS}

Various studies have been undertaken to describe factors influencing student throughput within traditional and ODL contexts (Prinsloo, 2009:6). Over the years several models of student retention or dropout within higher education have been developed, e.g. Bean (1980, 1982), Tinto (1982, 1988), Biggs (1989), Eaton (2000), and Stratton, O'Toole and Wetzel (2008) (Prinsloo, 2009:31). Earle (2008:109-134) made a valuable contribution to this body of literature by identifying factors affecting the graduate numbers and quality of students graduating in Social Work in South Africa. In her study aimed at developing an understanding of the professional milieu and professional labour market of social workers, she undertook two case studies of South African higher education institutions contributing to the supply of social workers in the local labour market, namely the University of Stellenbosch, a historically advantaged university, and the University of Limpopo, a historically disadvantaged university. The factors identified (Earle, 2008:109-134) are outlined below.

The quality of output from the secondary education system

All social work educators, both from the University of Stellenbosch and the University of Limpopo, who were interviewed by Earle (2008:110) considered the declining quality of high school education as a concern. At Stellenbosch this has impacted most significantly on admissions to the university and the Faculty of Arts and Social Sciences in which Social Work is housed, while at the University of Limpopo it has impacted more directly on throughput after admission. The levels of literacy and written communication skills were of concern. Students consulted at both universities indicted that school had not prepared them sufficiently for the volume of reading, level of writing or the levels of personal academic responsibility required to succeed.

\section{The national funding of social work education}

Participants in Earle's study (2008:112) considered the low levels of national funding for social work education to be the second key factor impacting on Social Work student throughput. In 1987 the universities and the South African Council for Social Service Professions (SACSSP) reached an agreement that registration as a social worker required a four-year university education. Because of a lack of negotiation with the Department of Education (DOE) around the funding implication of this change, the fourth year received undergraduate rather than 
Honours-level of funding. Adding to this was the shift of focus of higher education output away from the humanities. Social Work, along with nursing and teaching, is considered to be in the lowest funding category, D4. Funding also ignores that Social Work is a professional degree which has a training component in theory, practice and research. In both the University of Stellenbosch and the University of Limpopo this lead to a reduction of staff as well as the progressive erosion of programme depth and breadth. The University of Limpopo appointed more contract staff, but felt that these staff members were often less qualified and less committed than permanent staff (Earle, 2008:112-115).

\section{DOE funding linked to programme pass rates}

According to Earle (2008:115), another key aspect of the problems related to the national funding of higher education that impacts on the throughput of Social Work students lies in the directives of the National Plan for Higher Education. The 2001 National Plan for Higher Education included graduate outputs as an integral component of a revised funding framework, linking funding to the number of graduates produced. This seemed to create a tension with the objective of increasing demographic diversity set in the 1997 White Paper for the Transformation of Higher Education. Both universities which participated in the study experienced a tension between the efforts to maintain throughput and efficiency, while at the same time increasing demographic diversity. One of the supervisors at the University of Limpopo (Earle, 2008:116) stated: "For as long as there is the problem of having to push students through - [the universities] might be helping themselves, but they are not necessarily helping the profession."

\section{Students' motivation for undertaking the course}

In her study Earle $(2008: 117)$ found that the reasons why students undertake to study Social Work are linked to the individual pass rate and institutional throughput. Students who generally finish the course and go on to work as social workers seem to be those whose main motivations for undertaking the course are to help people, make a difference, see it as a calling and decide to go into the profession despite the poor pay and working conditions. Students less likely to complete their qualification are those who are unsure of their choice, who choose the degree because they consider it an easy option, who could not get access to their first-choice courses or who consider having the certainty of a job more valuable than the actual level of pay. The University of Limpopo had to abandon their selection criteria in 2001. While they were in place, only the stronger students who could explain their reasons for choosing the course could get in, while at present anyone with even a vague interest can enter the course. Staff members felt that the decline in the throughput figure of the University was linked to problems with students' motivation (Earle, 2008:118-119).

\section{The character of students}

In the study the desirability of a sound character and certain personal characteristics in student social workers were stressed. At both the University of Stellenbosch and Limpopo lecturers and supervisors noted the influence of severe attitude problems of students manifesting in, for example, contempt for authority, disrespect for clients and colleagues, inappropriate verbal and non-verbal communication, sloppy work and a disregard of deadlines (Earle, 2008:118-119).

\section{Access to finance}

Students' access to the finances required to support their studies was identified as another key factor impacting on throughput (Earle, 2008:120-122). A lack of finances not only acts as a barrier to entry to the course, but is also an ongoing concern to students, having a direct impact 
on their academic success. A lack of finances not only causes emotional stress, but can also leave students' basic needs for food and shelter unfulfilled and can lead to a lack of access to support materials such as textbooks. At the University of Limpopo almost all students indicated that finances were a massive concern, while at the University of Stellenbosch the problem was less acute and less widespread.

\section{Personal and family circumstances}

Earle (2008:122) found personal and family circumstances to be another important key factor influencing throughput: "Students' personal and family circumstances impact substantially on their ability to complete a degree in Social Work successfully. With the changing demographics of Social Work students, the majority are now from previously disadvantaged backgrounds, and bring the burden of these circumstances with them to the course." Almost all students from the University of Limpopo and a sizable portion of those from the University of Stellenbosch have first-hand experiences of issues such as alcoholism in families, teenage pregnancies, breakdown of families, lack of support from uneducated parents or grandparents, and a lack of access to technology and educational resources.

\section{Support for theoretical learning}

This study (Earle, 2008:124-125) has shown that the support available to students for the theoretical aspects of their learning has a considerable impact on throughput. This includes access to knowledgeable lecturers, academic support programmes, textbooks, computers, internet, journals, books and adequately equipped venues. In respect of access to lecturers and textbooks as well as academic support, the study showed students from the University of Stellenbosch having an advantage over those from the University of Limpopo.

Structure of, and support for, practical education

The last factor identified by Earle's research (2008:125) as impacting on student throughput is the structure and support for practical education. While common outcomes have to be met for achievement of the BSW, the means by which these outcomes are met and the number of practical hours at each academic level have not been prescribed. The context of the specific environment in which the student gets to apply the theoretical knowledge and the support they receive in this process will also have an impact on the quality of their education. These factors differ not only between various institutions, but also depend on the individual placement of students.

Earle (2008:134) summarises factors having a negative impact on Social Work graduate quality and throughput as follows: low levels of funding allocated to tertiary institutions for Social Work studies, linking of funding allocations to successful graduations, inadequate academic preparation of students from the secondary education system, personal social problems amongst students, limited availability of physical and human resource support within departments of Social Work to assist students in overcoming past disadvantages, a lack of finances to adequately cover tuition costs, personal needs and support materials, as well as students pursuing the career solely for reasons of guaranteed employment or other perceived perks. She identifies factors that positively affect social workers graduating in a minimum time as including having access to sufficient finances, having sufficient support and being motivated by reasons such as a feeling that social work is a calling, wanting to help others or making a difference despite knowledge of less-than-ideal working conditions and salaries. 


\section{RESEARCH ON THE PROFILE OF SOCIAL WORK STUDENTS STUDYING THROUGH UNISA}

In order to support their students, the Department of Social Work of Unisa wanted to understand the experiences of their students studying Social Work within on ODL context. Extensive research has been done by Lintvelt (2008), Lawlor (2008) and Wade (2009) on the profile of fourth-year student social workers within their personal, learning and practical work contexts.

Lintvelt (2008:112-134) found that participants carried a heavy load of responsibilities - caring for children and family members and looking after the household. Participants experienced difficulties with time management, being lonely while studying, death of loved ones, strained family relationships, poverty and a lack of safety. Participants experienced difficulty getting hold of Unisa staff by phone, were frustrated with long queues at registration, not getting their study material on time, prescribed books not always being in stock, books in the library being outdated and not enough study space being available. A large number of the participants studied in their second language. Participants felt they had to wait a long time for feedback on assignments. Students identified fellow students as a support system and described themselves as confident, hard-working and committed.

Lawlor (2008:99-114) focused on the personal, work and learning contexts of participants. Within the personal context she found that students generally experienced support from their families, that they still wished to grow on a personal and professional level, and expressed a need for computer literacy and counselling services to deal with their own issues.

Wade (2009) focused on trauma experienced by student social workers. She found that participants were exposed to multiple sources of trauma, e.g. physical or sexual abuse, death of a significant other, HIV/AIDS and crime, and also found that most students did not receive help in dealing with trauma (Wade, 2009:501).

Both Lintvelt (2008:133) and Lawlor (2008:113) recommended that similar research should be undertaken on a regular basis as students' needs may change. Lintvelt (2008:124), Lawlor (2008:110) and Wade (2009:105) recommended that Unisa should support students through difficult times.

\section{RESEARCH BACKGROUND}

During November 2009, 280 fourth-year students had to be placed at welfare organisations for their block placement in Gauteng. Since not enough traditional placements could be found, it was decided during a staff meeting that 20 fourth-year students would, as part of a pilot project, render peer support in the form of case, group and community work to 200 second-year students. A colleague and researcher contacted all first-year students (of 2009) staying in the Pretoria/Sunnyside area by sms to invite them to a meeting on 26 November 2009 at the Sunnyside campus to assess their interest in being part of this pilot project.

\section{RESEARCH METHODOLOGY}

Since the students would meet to assess their interest in participating in the project, it was decided to use this opportunity to undertake qualitative research on a small scale and to take the research done by Lintvelt (2008), Lawlor (2008) and Wade (2009) a small step further by exploring not only what students experience as obstacles in learning social work within an ODL context, but also the facilitative opportunities. Their view of facilitative opportunities could inform possible support programmes that might influence student success and 
throughput. The research question was formulated as: "What are the obstacles and facilitative opportunities experienced by Unisa Social Work students in preparing themselves for the social work profession?" A qualitative approach was followed, since the research questions were open-ended, evolving and non-directional (Creswell, 1998:99) An exploratory and descriptive design was used as little was known about this area and experiences could be further described or classified (Terre Blanche, Durrheim \& Painter, 2006:44).

\section{POPULATION AND SAMPLING}

The population of the study consisted of all first-year students of 2009 staying in the Pretoria/Sunnyside area. This is in contrast with the studies of Lintvelt (2008), Lawlor (2008) and Wade (2009), who all focused on fourth-year students. A convenience sample was taken of the students who were invited to a meeting to assess their interest in participating in a peer support programme. Participants were thus available for another reason (Alston \& Bowles, 2003:88).

\section{COLLECTING DATA AND DATA ANALYSIS}

A self-administered questionnaire, covering personal details and asking six questions, was handed out to students who met the above criteria. Four closed questions were asked about their interest in participating in the peer programme. The research, however, focused on two open questions, namely: "What do you experience as obstacles in your studies in preparing for the social work profession?" and "What in your opinion can facilitate your studies in preparing for the social work profession?”

A total of 117 questionnaires were completed. The information on the open questions was analysed according to the three steps described by Sarantakos (1998 cited by Alston \& Bowles, 2003:207): data reduction - the stage where data are coded, summarised and categorized; data organisation - the process of assembling the information around certain themes; and lastly, the presentation of the results and interpretation.

\section{FINDINGS AND DISCUSSION}

For the purposes of this article, the researcher will focus on the information received on the open-ended questions, since the closed questions only assessed the students' interest in participating in the peer programme. Findings are presented in table format. 
TABLE 1

OBSTACLES WHILE STUDYING SOCIAL WORK WITHIN AN ODL CONTEXT

\begin{tabular}{|c|c|}
\hline Theme & Sub-themes and quotes \\
\hline \multirow[t]{3}{*}{$\begin{array}{l}\text { Inadequate } \\
\text { service } \\
\text { delivery }\end{array}$} & $\begin{array}{l}\text { Unisa: Students reported that study material and results were late, assignments } \\
\text { were lost, phones were not answered and students were only allowed to register } \\
\text { for tutorial classes in three modules: } \\
\text { "I need to attend more modules, not } 3 \text {, more, at least } 5 \text {." } \\
\text { "Delay of study material, service delivery was very poor for 2009, hoping for } \\
\text { the best for 2010." }\end{array}$ \\
\hline & $\begin{array}{l}\text { Department of Social Work: Students felt they did not have enough access to } \\
\text { lecturers, communication was not enough: } \\
\text { "Preparing assignments is an obstacle because you need to find people, you } \\
\text { did not make an appointment and they turn you down. Poor communication } \\
\text { with lecturers." } \\
\text { Students expressed a need for more workshops, meetings and practical } \\
\text { activities, thus more contact learning: } \\
\text { "I think more regular classes would be of help." }\end{array}$ \\
\hline & $\begin{array}{l}\text { They identified a lack of information about modules, assignments and activities } \\
\text { during the year: } \\
\text { "I experience a problem with lack of information concerning the activities that } \\
\text { is taking place during the year." } \\
\text { Students experienced a lack of motivation and guidance as they were not sure } \\
\text { whether they were making progress as they should: } \\
\text { "I need a little guideline or guidance towards my studies." }\end{array}$ \\
\hline $\begin{array}{l}\text { Personal } \\
\text { obstacles }\end{array}$ & $\begin{array}{l}\text { Personal circumstances or problems sometimes prevented them from attending } \\
\text { workshops: } \\
\text { "I'm not able to talk to others about personal problems that I'm having, for } \\
\text { instance, I just recently found out that I am an adopted child in the household, } \\
\text { and can't be able to open up about it." }\end{array}$ \\
\hline $\begin{array}{l}\text { Lack of } \\
\text { resources }\end{array}$ & $\begin{array}{l}\text { Students identified a lack of finances, means of travelling, a need for skills, } \\
\text { language barriers, disability, a lack of time management and lack of self- } \\
\text { confidence as obstacles: } \\
\text { "Planning for studies, if planned lack of discipline due to lot of work and } \\
\text { family commitment." } \\
\text { "My obstacles in my studies in preparing for the social work profession its } \\
\text { shortage of finances, because I really want to go further with the career." } \\
\text { They were of the opinion that they lack information on the social work } \\
\text { profession: } \\
\text { "Getting enough information from our lecturers regarding the social work } \\
\text { profession." } \\
\text { Students also referred to feeling isolated, staying far from other students: } \\
\text { "Spending long time being alone in my studies." }\end{array}$ \\
\hline
\end{tabular}

In the second question students included aspects which they experience as facilitative as well as suggestions which could contribute to a more positive learning environment. 
TABLE 2

FACILITATIVE EXPERIENCES WHILE STUDYING SOCIAL WORK WITHIN AN ODL CONTEXT

\begin{tabular}{|c|c|}
\hline & $\begin{array}{l}\text { Students felt that more guidance during registration and a workshop } \\
\text { immediately after registration could be beneficial, as well as an increase in } \\
\text { workshops, tutorial classes, practical work: } \\
\text { "Regular contact with lecturers through workshops." } \\
\text { These students preferred more face-to-face contact with lecturers or tutors and } \\
\text { encouragement or personal motivation: } \\
\text { "For the Department to put more focus on practical sessions." } \\
\text { They would like to attend to time management, report writing skills and } \\
\text { academic writing skills in a workshop or group context: } \\
\text { "Workshop on report writing should be conducted, also argumentative and } \\
\text { academic writing." } \\
\text { Only one student mentioned that access to internet will facilitate learning. }\end{array}$ \\
\hline Support & $\begin{array}{l}\text { Students identified counselling for personal or work-related issues or } \\
\text { discussing personal problems within a group as facilitative opportunities: } \\
\text { "If I can get counselling for my problem and help others or work hand in } \\
\text { hand with people experiencing the same problem through discussion." } \\
\text { They felt that peer support enhances learning and that it will be helpful to get } \\
\text { a list of names of students in their area to form a group to learn and socialise } \\
\text { together: } \\
\text { "If I get encouragement from my fellow senior students, I will achieve a lot." } \\
\text { Students stressed the importance of the role that senior students could play in } \\
\text { encouraging them and in serving as peer mentors: } \\
\text { "Meeting with other students, my peers and those ahead of me, share } \\
\text { experiences and learn from one another." } \\
\text { Students should be more involved in the social work profession by doing } \\
\text { voluntary or paid work, by participating in the field activities and receiving } \\
\text { supervision from a professional social worker: } \\
\text { "Interacting with people who have experience of what I am learning." } \\
\text { "...getting involved in volunteering activities, more especially at the NGO } \\
\text { organisations, by this you get an opportunity to grow as a future social } \\
\text { worker and more especially gain experience." }\end{array}$ \\
\hline $\begin{array}{l}\text { Inner } \\
\text { resources }\end{array}$ & $\begin{array}{l}\text { Students recognised their own responsibility in facilitating their studies } \\
\text { through self-discipline, commitment and using available information: } \\
\text { "Being committed to my studies and never give up." }\end{array}$ \\
\hline
\end{tabular}

\section{DISCUSSION}

Obstacles experienced by students when studying social work within an ODL context could in the long run negatively affect the success of their studies and thus the throughput rate, while facilitative experiences could enhance success. Inadequate service delivery, personal obstacles and a lack of resources correspond to some of the negative factors identified by Earle (2008:134), namely limited availability of physical and human resource support within departments of Social Work, personal and social problems amongst students, and a lack of access to sufficient finances to adequately cover personal needs, tuition and support material. Similar obstacles were also identified by Lintvelt (2008), Lawlor (2008) and Wade (2009). 
Facilitative experiences of students while studying social work in an ODL context can in the long run contribute to student success and throughput. Aspects categorised under the themes of service delivery, support and inner resources link to factors identified by Earle (2008:134) which positively affect Social Work throughput, namely having access to physical and human resource support necessary to overcome past academic disadvantages, dealing with individual social problems, as well as students being motivated by reasons such as seeing social work as a calling or wanting to make a difference.

What is new about the findings is the focus on the role of the social work profession. It seems that these participants on a first-year level are already identifying themselves with the profession and would like to work with social workers in order to learn through observation and being involved on a practical level. The potential role of the senior students in guiding and mentoring junior students also stood out. Another strong theme running through the comments on obstacles and facilitative opportunities is a need for encouragement and motivation from lecturers and senior students. The silence about technology could be an indication that student social workers are not ready to use e-learning or that they have not been made aware of the possible role that this could play. Participants saw individual and group counselling or support as a facilitative opportunity. This corresponds with the recommendation made by Lintvelt (2008:124), Lawlor (2008:110) and Wade (2009:105) that Unisa should support their students through difficult times.

\section{RECOMMENDATIONS AND CONCLUSION}

The recommendations from this study, focusing specifically on the experience of Social Work students within an ODL context, are the following:

- Lecturers should be more accessible to students. Modern technology can facilitate regular contact;

- Clear communication on what the students can expect from the specific career they are preparing for, the course as whole and specific modules and any curriculum changes is essential;

- Counselling on personal, work and study-related issues should be made available to all students;

- Peer support and encouragement from senior students can play a significant role;

- Efforts of various departments should be coordinated in supporting students. Tutors should be trained by lecturers, while students should be made aware of the programmes and services of the student support division as well as resources offered within the wider institution;

- Early contact with representatives of the profession for which students are preparing themselves, e.g. voluntary work can facilitate the development of a specific professional identity;

- Technology and forms of e-learning can be used more effectively, but students need to be prepared for it.

If lecturers at universities who are training student social workers could understand and act on factors contributing to student success at their specific institution, it could lead to an increase in the throughput rate of Social Work students and thus to the required number and quality of social workers needed in South Africa. Knowing what their students experience as obstacles and facilitative opportunities in studying Social Work could assist them in a practical way. 


\section{REFERENCES}

ALSTON, M. \& BOWLES, W. 2003. Research for social workers: an introduction to methods. London: Routledge.

ASHBY, A. 2004. Monitoring student retention in the Open University: definition, measurement, interpretation and action. Open Learning, 19(1):65-77.

COLLINS, S. 2008. Open and distance learning in qualifying social work education in Britain and the USA: celebrating diversity and difference. Social Work Education, 27(4):422-439.

CRESWELL, J.W. 1998. Quality inquiry and research design: choosing among five traditions. London: Sage Publications.

EARLE, N. 2008. Social work in social change. The profession and education of social workers in South Africa. Cape Town: HSRC Press.

LAWLOR, G.M. 2008. Examining the fit between personal, learning and practical work contexts of students to further practice excellence in social work training. Pretoria: University of South Africa. (MA Dissertation)

LINTVELT, R.A. 2008. The personal contexts of undergraduate students in social work at UNISA. Pretoria: University of South Africa. (MA dissertation)

PRINCIPAL. 2006. Principal's statement to senate. Pretoria: University of South Africa.

PRINSLOO, P. 2009. Discussion document. Modelling throughput at Unisa: the key to the successful implementation of ODL. Directorate for Curriculum and Learning Development. Pretoria: University of South Africa.

QAKISA-MAKOE, M. 2005. Reaching out: supporting black learners in distance education. Progressio, 27(1\&2):44-61.

SCHENCK, C.J. 2008. Should being a South African make social work training different? Towards giving new meaning to the concept "student-centredness". Inaugural lecture 21/10/2008. Pretoria: University of South Africa.

TERRE BLANCHE, M., DURRHEIM K. \& PAINTER, D. 2006. Research in practice. Applied methods for the social sciences. Cape Town: UCT Press.

UNISA (University of South Africa). 2008. Five years transformation 2004-2008. Pretoria: University of South Africa.

WADE, BL. 2009. UNISA social work students' experiences of trauma: an exploratory study from a person-centred perspective. Pretoria: University of South Africa. (DPhil Dissertation)

Ms Petro Botha, Department of Social Work, University of South Africa, Pretoria, South Africa. 


\title{
CHALLENGES AND CHANGES IN TEACHING PERSON-CENTRED COUNSELLING TO SOCIAL WORK LEARNERS VIA DISTANCE EDUCATION
}

\author{
Desirée de Kock
}

\section{INTRODUCTION}

This article focuses on the quest to be learner-centred in social work training and on the challenges faced by the Department of Social Work at the University of South Africa (UNISA) in teaching person-centred counselling skills to Social Work students via open distance learning. The author first explores the meaning of open distance learning and learnercenteredness, then briefly discusses the theoretical framework supported by the department in teaching Social Work and lastly discusses the strategies used and challenges faced in teaching person-centred counselling skills to Social Work students at UNISA, with recommended changes in addressing these challenges.

\section{UNISA AS AN OPEN DISTANCE EDUCATION INSTITUTION}

In the field of higher education UNISA needs no introduction to social workers in South Africa. UNISA has been teaching and training social work students for the past 68 years. First studying through UNISA was labelled as correspondence and from 1946 until 2003 as distance education (UNISA, nd:5). After the merger between UNISA and the Technikon Southern Africa and the incorporation of VUDEC (the distance education section of the then Vista University) in January 2004, the new UNISA revisited the role of the new institution in South Africa, Africa and globally. UNISA then became a comprehensive tertiary institution, which means that the University offers degrees and diplomas with an academic and vocational focus. The content of most of the degrees offered is academically focused, and that of the National Diplomas has a more vocational focus, with experiential learning as a core component of the qualification (UNISA, 2005:2). Since 2005 UNISA has been known as an open distance learning institution.

What does an "open distance learning institution" mean? This means that UNISA is open to registration for any student who meets the minimum requirements to access the University. Although the profile of UNISA students' has changed from almost all registered students being full-time employed to an increasing number of younger students and students who are not employed (20\%), UNISA is still not a residential university, but presents courses in a distance education mode (UNISA, 2010).

In the establishment of the new institution UNISA formulated its vision as: "Towards the African University in the service of humanity" (UNISA, nd:6). UNISA's commitment to service delivery to students is reflected in the following excerpts from the mission statement that it:

- "provides quality general academic and career-focussed learning opportunities underpinned by principles of lifelong learning, flexibility, and student-centredness;

- is accessible to all students, specifically those on the African continent, and the marginalized, by way of a barrier-free environment, while responding to the needs of the global market" (UNISA, nd:7).

The values supported by UNISA include integrity, social justice and fairness and excellence. The values of social justice and fairness specifically relate to the paradigm of open distance 
learning as it focuses on "promoting equity of access and opportunity so that all may develop their full potential" (UNISA, nd:6).

The UNISA Open Distance Learning Policy document (2008:2) defines open distance learning as "a multi-dimensional concept aimed at bridging the time, geographical, economic, social, educational and communication distance between student and institution, student and academics, student and courseware and student and peers. Open distance learning focuses on removing barriers to access learning, flexibility of learning provision, student-centredness, supporting students and constructing learning programmes with the expectation that students can succeed"

\section{BEING LEARNER-CENTRED IN OPEN DISTANCE LEARNING}

Learner-centeredness within the UNISA context is supported by the following statements in UNISA policy documents:

"Prioritising student needs and basing decisions on student profiles" (UNISA, 2007:3) as well as the statement that learner-centeredness "requires that students are seen as the main foci of the educational process and they are supported to take progressive responsibility for their learning and research. However, the pedagogy employed should enable successful learning through rich environments for active learning; establish links between students' current meaning and contexts and new knowledge to be constructed, and encourage independent and critical thinking." (UNISA, 2008:2)

The Institutional Operational Plan 2010 also specified goals such as the development of:

- integrated student-centred pedagogically sound courseware;

- the integration of pedagogy and technology such as myUnisa and myLife;

- the integrated student-support model;

- the improvement of regional facilities with video-conferencing and satellite delivery services.

The Interim Institutional Operation Plan 2011-2013 also emphasise the crucial need to "improve online learning facilitation through the use of technology" with the aim of having "technological infrastructures with pedagogical capacities fully integrated" by 2013 (UNISA, 2011:10).

\section{THE DEPARTMENT OF SOCIAL WORK, STUDENT-CENTEREDNESS AND OPEN DISTANCE LEARNING}

In this section the focus is on the philosophical and theoretical frameworks taught by the Department of Social work within the open distance learning paradigm and student-centred philosophy of UNISA.

Philosophical and theoretical frameworks

In teaching Social Work in South Africa all universities must meet the exit-level outcomes of the Baccalaureus in Social Work (BSW) qualification as registered with the South African Qualifications Authority (SAQA). At UNISA the Department of Social Work teaches these exit-level outcomes from specific frameworks, namely a postmodernist and constructivist approach, and teaching counselling skills based on the person-centred approach.

The constructivist claim is that people "do not just 'experience' the world objectively or directly" (Moses \& Knutsen, 2007:10). People's experiences are channelled through their 
minds, meaning that people may look at the same thing and perceive it differently. This is influenced by individual characteristics such as age, gender, race and nationality. This is furthermore complicated by social characteristics such as culture and language. Within a constructivist frame of reference we want to capture and understand the meaning of social action for the agent performing it. When something is meaningful or real to the person, it may affect his/her behaviour and have real consequences for the society around this person. For the constructivist there is no absolute truth; the focus is on the experiences of people, how they perceive them and how they contextualise them. The observer forms part of the context of what is happening and there is always an element of subjectivity present (Moses \& Knutsen, 2007:11-12; Terre Blanche \& Durrheim, 2002:6; Zima, 2007:171).

The postmodern paradigm also makes no claim to absolute "truth", and no specific theory or method is better than another in determining the truth. The truth is relative to what the individual or community believes to be true. Therefore social scientists are always linked to their social and historical context and it is not possible to conduct a value-free enquiry into social issues. Furthermore social reality is constructed and social scientific knowledge is a construct of social inquiry. Lastly, social reality always exists as part of human reflection and inquiry (Babbie \& Mouton, 2002:40).

The person-centred approach (PCA) to counselling in Social Work has been the centre of teaching counselling skills at the UNISA's Department of Social Work for the past 13 years. This approach focuses on the self or identity of the person, group or community. "It looks at those experiences that the client cannot allow into his or her conscious mind, because the experiences threaten the client's perception of who he or she is" (Grobler \& Schenck, 2009:4). To deal with these threatening experiences through the PCA to counselling, the social worker as facilitator needs to accept the client and enable clients to see themselves and all of their experiences more clearly. This approach emphasises that the client is the expert about his or her circumstances and not the social worker or facilitator. Each individual perceives their situation differently from they way others do as a result of their own conscious and unconscious experiences, needs, their interaction with the environment and significant others, value systems and many more other factors. In facilitating this process, the focus is on the strengths of the person and not the presented problem. Every individual has their own frame of reference, has to discover their own strengths and determine their self-development. This approach also fits with the constructivist and postmodern theoretical frameworks the Department has adopted. Furthermore, this approach to counselling in Social Work supports the paradigm shift within the social welfare field to deliver social services from a developmental rather than a pathological perspective, as well as to develop the independent functioning of individuals, groups and communities (White Paper for Social Welfare, 1997).

\section{Student-centeredness in the Department of Social Work}

To ensure that our training is student-centred, supportive and empowering in nature, several research studies were conducted. Research done by Lintvelt (2008:29-31, 45, 50) provided the Department of Social Work with the following profile of our students:

- The majority of the UNISA students are female;

- In the $4^{\text {th }}$ year the majority of the students are between 31 and 35 years old;

- The majority (75\%) are involved in a special relationship;

- The majority (53\%) have their own children; and 
- The majority grew up with their own parents, who were employed.

The living conditions of students during their studies at UNISA are characterized by the following features:

- Poor housing;

- Being victims of crime;

- Household responsibilities;

- Very difficult financial conditions;

- Concern about low remuneration; and

- Burden of study loans (Lintvelt, 2008:87 ).

Wade (2009) conducted a study pertaining to trauma experiences of 98 fourth-year students in 2006 and 124 fourth-years in 2008; these were students studying Social Work at UNISA. Some of her key findings were:

- The highest number of experiences of traumatic events by one students was 32 ;

- The lowest experience of traumatic events by a student was one;

- The average experiences of traumatic events is 13 ; and

- The majority of students experienced between six to 16 traumatic events (Wade, 2009:338).

The challenge of growing student numbers

When social work education was introduced at UNISA in 1942, it formed part of the Department for Sociology and Criminology. The Department of Social Work was established in 1960 (Van Dyk, 2009). Thirty years later, in 1990, we had 80 first-year learners, and by 2007 that number had grown to 5 697. The increase in student numbers per module is as follows:

TABLE 1

RANGE OF STUDENT ENROLMENTS FOR SOCIAL WORK MODULES IN 2010 - 2011

\begin{tabular}{|c|c|c|c|c|}
\hline $\begin{array}{l}\text { Academic } \\
\text { year level }\end{array}$ & $\begin{array}{c}\text { Range of registra- } \\
\text { tions in } 2010\end{array}$ & $\begin{array}{c}\text { Range of registra- } \\
\text { tions in 2011 }\end{array}$ & $\begin{array}{c}\text { Practical module } \\
\text { enrolments 2010 }\end{array}$ & $\begin{array}{c}\text { Practical module } \\
\text { enrolments 2011 }\end{array}$ \\
\hline First year & $3202-3965$ & $3926-4811$ & 3202 & 3926 \\
\hline Second year & $1340-3000$ & $1905-2326$ & 1417 & 2326 \\
\hline Third year & $727-992$ & $726-1131$ & 1494 & 1447 \\
\hline Fourth year & $261-421$ & $291-393$ & 862 & 919 \\
\hline TOTAL & 30526 & 33664 & 6975 & 8618 \\
\hline
\end{tabular}

In teaching Social Work at UNISA the lecturing staff (11 full-time staff members, including the Head of the Department) teaching the undergraduate students are also responsible for the development of the study material to guide and support students through their learning process. There are no lectures and therefore these study guides must be of such a nature and quality that they guide the student through the prescribed book(s) and the understanding of the theory as well as the development of practical skills they need to apply in practice after their graduation. Six of these staff members, with the assistance of an additional four full-time staff members, are also responsible for the supervision of postgraduate students in Social Work. 
"The Department of Social work strives to promote the ideals of democracy, social transformation and social justice. We aim to practically apply the fundamental principle of the University of South Africa's vision, namely to be 'in service of humanity'. Our teaching strives towards academic excellence and relevance congruent with the ethos of the profession of Social Work and within the parameters of the Act on Social Service Professions (Act 110 of 1978 as amended). Our training is student-centred, supportive and empowering in nature" (Social Work, 2010). In adhering to the nature and demands of open distance learning we facilitate the study process for our learners by sending them study guides, tutorial letters and DVDs, which they use in conjunction with the prescribed books they have to buy. The lecturers are a telephone call away and can also be contacted via e-mail or the myUnisa online student portal. The Student Support Unit, in cooperation with academics, appoints tutors who assist learners at the first- and second-year levels by presenting face-to-face classes. In some modules lecturers also arrange discussion classes and workshops, which bring them into face-to-face contact with the learners.

Although open distance learning has its own challenges, it is in particular the increase in student numbers in the practical modules which poses a challenge to the Department.

\section{TEACHING PERSON-CENTRED COUNSELLING TO SOCIAL WORK LEARNERS VIA DISTANCE EDUCATION}

In this discussion the author briefly refers to the contribution of the theoretical modules, but focuses on the teaching of these skills in the practical modules.

\section{CURRENT EDUCATION AND TRAINING OF THE PERSON-CENTRED APPROACH (PCA)}

First year of study

In the first year of study learners have three compulsory social work modules, namely Welfare Policy (SCK101W), Introduction to Social Work and the Helping Process (SCK102X), and Social Work Practica (SCK103Y).

Apart from being given a historical and chronological overview of the development of social welfare and social work in South Africa, and being introduced to the most important policies and legislation frameworks, learners are introduced to the vision of development and empowerment in South Africa. In this regard, Van Dyk (2006) refers to the concept of ubuntu and the connection between ubuntu and the person-centred approach, as well as to the philosophy inherent to the person-centred approach. These concepts are explained to the learners by connecting person-centeredness with being people-centred, and they are illustrated with reference to the realities in South Africa.

In the module Introduction to Social Work and the Helping Process, learners are introduced to the theory and philosophy inherent in the person-centred approach to counselling (helping), the values and ethics in social work, and how the two connect with each other. Learners are introduced to basic concepts such as congruence, unconditional positive regard, empathy and personal power, which are further explained by using real-life scenarios and case studies (Van Dyk, 2000).

In the module Social Work Practica learners have to compile a portfolio. In preparing the portfolio they have to study sections B and C in their prescribed book by Grobler and Schenck, 
Person-centred facilitation: Process, theory and practice (2009). These sections deal with the facilitator's values and putting thinking and values into practice (Mbedzi, 2009a).

In the portfolio learners have to apply their knowledge through the following activities:

- substantiating social work as a career choice, describing the characteristics of a good social worker and describing their own characteristics;

- compiling a community profile by identifying general resources, welfare organisations, groups and people with influence, social, cultural and religious differences, and welfare issues in the community;

- writing down their own thoughts about child abusers, religious beliefs, non-believers and gender issues such as the election of males as presidents - and thereafter identifying their own prejudices, stereotyping and discriminatory thoughts around these issues;

- learning about the value and belief systems of other people and experiencing different frames of reference by exposing themselves to a group with a different belief system than their own, or by visiting a place they would normally not visit and documenting their experiences (Mbedzi, 2009b).

During each academic year the Department of Social Work arranges three discussion classes for learners who are enrolled for the practical module. The aims of these discussion classes are to discuss the activities for the portfolio, the values of the facilitator and facilitation skills. Because of the large number of learners registered for this module, the discussion classes are not compulsory. In addition to the 9344 registrations for the theory modules, 3926 learners registered for Social Work Practica in 2011. These portfolios are all assessed and count towards the students' examination mark for SCK103Y.

Second year of study

Six modules are presented in the second year of Social Work, and learners have to choose five. The modules are:

- Facilitating Communication with People in Groups and Communities (SCK2013);

- Practical Guide to Facilitating Communication in Groups and Communities (SCK2024);

- Welfare Policy (SCK2035);

- Life Tasks, Obstacles and Resources and Competence (SCK2046);

- Marriage Guidance: Facilitative Couples Counselling (MGG201W);

- Sexual Trauma (MGG202X).

The module Facilitating Communication with People in Groups and Communities focuses specifically on introducing the learners to the theory of the person-centred approach in counselling. Although the focus is on groups and communities, reference is also made to working with individuals. Learners have to study the basic PCA concepts, the 19 propositions, and be able to apply these propositions to group work and community work situations. We also focus on values, ethical issues and the basic skills in the person-centred approach. The study guide gives examples to learners in the format of scenarios and case studies. Empowerment, the fact that the community/group/person is the expert on their circumstances, and the personal strength of the client are emphasised (Mohapi \& Schenck, 2006a). The prescribed books which focus on the PCA for this module are: 
- Grobler, H. \& Schenck, R. 2009. Person-centred facilitation: Process, theory and practice $\left(3^{\text {rd }}\right.$ ed). (This book is prescribed from the first to the fourth year of study.)

- Tolan, J. 2003. Skills in person-centred counselling.

In the module Marriage Guidance: Facilitative Couples Counselling the learners are introduced to a number of theories used in counselling. However, special attention is given to the PCA, because in the Department of Social Work at UNISA we believe that this is an approach that embraces, firstly, the values and beliefs needed for people to take control of their own lives, and secondly, the principles of empowerment and development (Petty, 2006).

Up to this point the focus has been on the theory in the education and training of social work learners. The Practical Guide to Facilitating Communication in Groups and Communities focuses on teaching learners how to apply the PCA; to learn how to create the conditions for person-centred counselling, and to learn the basic skills in working with symbolised experiences such as attending, listening, probing and empathy. Learners also have to integrate their theoretical understanding of the 19 propositions and identify how these apply in practice in working with groups, communities and ultimately individuals. Apart from the more than sixty activities in the workbook that the learners have to work through, until 2009 this was taught through a total of four to five workshops with the learners, conducted over a period of five months (a total of 12 days). The learners work in groups and practise the basic skills through role plays, case scenarios and observation exercises. They also have to compile a portfolio based on the activities given in the workbook and additional activities given to them by the workshop supervisors. The learners are also introduced to advanced skills such as advanced empathy and immediacy (De Kock, 2009; Mohapi \& Schenck, 2006b).

For 2009 we had 916 learners registered for this course, of whom 12 resided outside the borders of South Africa. The workshops were conducted by 37 workshop supervisors at 17 centres in South Africa and one workshop supervisor in Gaborone, Botswana. The ideal number of learners allocated to a workshop supervisor should be 12 to 15 . However, because of the large number of learners and the limited number of workshop supervisors as well as the limited physical resources, the average ratio of workshop supervisor to learners in 2009 was 1:20. Of the 46 workshop sessions presented by the 38 workshop supervisors, only 10 groups have 15 or fewer learners attending. This increase in numbers challenged the human and physical resources available to the Department of Social Work.

During 2009 the Practical Guide to Facilitating Communication in Groups and Communities was reworked and in 2010 students received a Workbook to Facilitate Communication in Groups and Communities as Tutorial Letter 501 of 2010 (De Kock, 2010). In the workbook activities are linked with what students had to do in their first year and the activities were constructed in such a way that students could complete them on their own. Therefore no workshops were presented. The students had to complete the workbook activities and submitted it as a portfolio of evidence of their understanding and application of the PCA in counselling. All these portfolios were marked and counted towards the students' examination mark.

Third year of study

In the third year the Social Work curriculum consists of five social work modules, apart from their second major (Psychology, Criminology, Philosophy or Anthropology). These are:

- Social Casework (SCK3016);

- Theory, Values and Skills for Work with Groups and Families (SCK3028); 
- Community Work (SCK3039);

- Guidelines for Practical Case, Group and Family Work (SCK304A);

- Community Work Practicals (SCK305B).

At this level learners learn in depth about the social work methods relating to casework, group work and community work. They also learn how to apply the PCA to counselling in these methods. The first three modules mentioned are theory-based and the theory is put into practice for the learners by making use of examples and case studies (Grobler, 2009a; Grobler, 2008a; Louw \& Dicker, 2001).

In the practical modules the basic skills learned in the second year are revised, and advanced counselling skills such as advanced empathy and immediacy in working with unsymbolised experiences are added. The compulsory requirements for the Case, Group and Family Work module at this level are as follows:

SCK304A Case, Group and Family Work:

- One half-day orientation session;

- Three 3-day workshops (full day)

- Five half-day group supervision sessions;

- One half-day evaluation session;

- One half-day practice session (Grobler, 2009b).

The integration of theory, values and skills is a central part of the practical work in the third year. In the abovementioned workshops the learners work with the workshop supervisors to reach this integration through role play, case studies and simulated situations. The content of the workshops includes working with individuals, families, children, groups and statutory work from a person-centred perspective. During the group supervision sessions, attention is also paid to adults and children in different and challenging situations, which range from experiencing medical difficulties such as losing a limb to abuse and crime-related and work-related issues. Attention is also given to various difficulties the social worker may encounter.

The aims of the module Case, Group and Family Work are that learners "will be able to understand and apply, in simulated situations with individuals (both adults and children), the following themes:

- the person-centred theory (the 19 propositions of Rogers)

- the values associated with the theory

- the skills (both basic and advanced) of the person-centred theory

- assessment and evaluation as part of the process of facilitation

- innovative ways of relating to and communicating with people

- awareness of and exploration of the development of your own professional self as facilitator" (Grobler, 2008b).

The Department of Social Work appointed about 35 workshop supervisors to assist the fulltime staff member who is responsible for the workshops and supervision of learners across the country. The ideal workshop supervisor to learner ratio is $1: 8$, but because of the fact that more than 753 learners registered for this module this year, the average ratio is 1:21. Many of our workshop supervisors in Durban, Johannesburg and Pretoria are responsible for more than one group of learners. 
The compulsory requirements for the Community Work module at this level are as follows:

SCK305B Community Work:

- One full-day orientation session;

- One 3-day workshop (full day);

- Two 2-day workshops (full day);

- One half-day evaluation session;

- Tasks, including workbook and portfolio activities (Grobler, 2009b).

The practical activities in community work entail a visit to an organisation which renders community services, the arrangement and execution of an awareness walk, creating a product/poster relating to participatory community development, compiling a community profile, as well as identifying the presence or absence of PCA behaviour and the propositions in videos or movies. This is also done through group activities and role play, under the supervision of the appointed workshop supervisors (Skhosana, 2009). The learners have to write reports on all their activities. In 2011 the Department of Social Work appointed approximately 35 workshop supervisors to assist the full-time staff member who is responsible for the workshops and supervision of the 710 learners across the country. Again, the ideal workshop supervisor to learner ratio is 1:8, but because of the large number of learners registered for this module the average ratio is 1:20. Here, too, many supervisors are responsible for more than one group of learners.

Fourth year of study

In their final year of study the curriculum consists of social work modules only. In the fourth year learners have to enrol for the theory and practical modules simultaneously. Because many of our learners are working while they are studying and have responsibilities as life partners and parents too, we advise them to complete the fourth year over at least two years. The theory, and especially the practical work, demands much from them and very few learners are able to complete all ten modules in one year.

The curriculum for the fourth year entails the following:

- Casework: work with individuals, couples and families (SCK401A) plus the practica (SCK402B);

- Group work: work with children, youth and adults (SCK403C) plus practica (SCK404D);

- Community work: the planning (SCK405E) and execution of a project (SCK406F);

- Social work management: the organisation (SCK407G), the employee and the manager (SCK408H);

- Research project: project planning and execution (SCK410B);

- Statutory work, ethics and supervision (SCK411C).

The level 4 practica are compulsory and are presented continuously from January to September each year. Besides being placed in an organisation, learners must attend regular workshops and supervised sessions. The process of placing learners with organisations to conduct the required practical work in their fourth year already begins in September the previous year. In January learners have to attend a full-day orientation workshop for the theory modules. At the end of January or beginning of February learners have to attend a block period of five days at the organisation where they are placed for their practica to get to know the organisation and 
undertake tasks. Besides this, learners have to spend at least eight hours per week at the organisation from February to the end of September in the year they are registered for practical work (Botha, 2009; Schenck, 2002; Schenck, 2009).

Learners registered for SCK402 (Casework) also have to attend three sets of two-day workshops, each of which focuses on working with individuals (adults, children) families, and on statutory work. Learners have to conduct at least 20 interviews while working with individuals, and must conduct at least one interview with a family after the second workshop. Learners have to work with one or more clients, depending on the needs of the client/s. The interviews may not be 20 once-off interviews. Telephone interviews are recorded as contacts, but do not count as part of the 20 interviews. Process notes must meet the prescribed requirements, which include the identification of the propositions that emerge during the interview and the skills applied during the interview.

Learners registered for SCK404D (Group Work) have to apply the social work group work processes and conduct eight group sessions (including the termination session) with adults or children. The learners also have to attend 51/2 workshop days scheduled from February to July each year. Again, with the group work they have to complete the required process notes, which have to reflect the group processes and interactions, the skills applied during the group sessions, and the related PCA theory (Buthelezi, 2002; Mohapi, 2009).

Learners registered for SCK406F (Community Work) have to apply the community work processes and conduct a community project, starting with making contact and building relationships, and then engaging the community in planning, executing and sustaining the project. They also have to attend five workshops scheduled from February to July each year (eight days altogether). With the community work, too, learners have to complete the required community work report, which has to reflect all the processes and interactions, the skills applied during the engagement with the community, and the related PCA theory (Du Plessis \& Louw, 2009).

Apart from the above, learners also have to attend supervision sessions with their supervisors from February to August. Learners are also expected to be involved with other activities required at the organisation where they are stationed, such as intake work and attending case conferences and staff meetings (Schenck, 2009). During May/June the three assigned lecturers in the Department of Social Work are involved with the half-year evaluations of the fourth-year learners and during September each year the final evaluations are done. These three lecturers responsible for these modules are assisted by the other full-time staff in the Department to do the assessments of the 291 learners registered for Casework; the 283 learners registered for group work; and the 345 learners registered for Community work. The learners have to submit a portfolio for each of the practical modules done during the year, and they have to prepare a 5minute presentation for the final evaluations. The supervisor and the contact person at the organisation have to report to the University about the functioning, progress and competence of each learner. The lecturer based in Durban is responsible for the assessment of the learners who conduct their practical work in KwaZulu-Natal. This included 180 learners for 2010 and 240 for 2011.

The ideal supervisor to learner ratio is 1:5. However, with an average of 306 learners in the practical modules and five lecturers and 40 supervisors involved with the supervision of the learners, it is no longer possible for us to realise the ideal ratio. This applies specifically to the 
areas with a higher learner population density such as Pretoria, Johannesburg, Durban and Polokwane.

Although the module Social Work Supervision and Ethics does not have a practical component, the theory, values and principles of the PCA are integrated in the presentation of this module (Van Dyk \& Harrison, 2008).

During 2007 Lawlor did research in determining the views of students, supervisors and the contact persons at organisations where students are placed for their fourth-year practical work. Lawlor $(2008: 61,83,95)$ reported the following findings in this study:

Student views:

- The majority (83\%) of the students who studied at UNISA stay in the profession;

- Seventy-two per cent $(72 \%)$ of the students are of the opinion that their education and training in Social Work at UNISA do equip them for practice; and

- They have a positive perception about the placements settings for their fourth year practical work.

The majority (61\%) supervisors indicated that the professional development and skills of UNISA Social Work students are better or the same as those of students from other universities. The contact persons at the organisations indicated that the behaviour of UNISA students with reference to punctuality is the same as those of students from other universities and $62 \%$ were of the opinion that the skills of the UNISA social work students are better or equal to those of students from other universities.

In his research Mbedzi (2010:21) indicated that there are no follow-up studies done in relation to the integration of theory by professional social workers. The only studies available were done in relation to fourth-year students. Mbedzi conducted his study with Social Workers who studied at UNISA and how they integrated PCA into practice. He also found that the majority of students who studied at UNISA utilise the PCA when they work as social workers. However, many of them do experience challenges due to high case loads, the expectations of organisations related to specific programmes or results as understanding and implementing PCA as a way of being and not only as a counselling approach (Mbedzi, 2010:74). The researcher is of opinion that this difficulty has a direct link with the challenges experienced in dealing with high student numbers which is indicated in this article.

\section{FUTURE EDUCATION AND TRAINING OF SOCIAL WORK LEARNERS IN THE PERSON-CENTRED APPROACH}

In this section the author focuses on current developments and recommendations for the future education and training of social work learners at UNISA.

Current developments

Taking into account the sharp increase in the number of learners registering for the BSW qualification over the past five years (with the number of learners increasing from 480 to 2326 in the second year; from 300 to 1447 in the third year, and from about 100 to 919 learners in the fourth year), the lecturers at the Department of Social Work had to revisit and rethink the format in which the practical modules are presented. The logistics around the management of the number of supervisors (170 in 2011) and venues available for workshops had become a real challenge. 
As previously indicated, the presentation of the practical module in the second year has already changed and the performance of these students in the examinations as well as their adjustment in their third-year practical work will indicate the success of these changes, which will only be known at the end of 2011.

The curriculum is still under review and the presentation of the practical modules for the third and fourth year is still under scrutiny. The Institutional Operational Plan of UNISA lists several of the objectives, such as:

- the development of integrated student-centred pedagogically sound courseware;

- the integration of pedagogy and technology (myUnisa \& myLife);

- the development of an integrated student-support model;

- the improvement of regional facilities, including video-conferencing and satellite delivery services, that will also enable the Department of Social Work to increase the effectiveness of the practical training offered to learners.

To innovatively manage the increase in student numbers and to decrease the distance in open distance learning we have to use technology to our advantage in teaching Social Work Practice at UNISA.

The increase in student numbers and limited resources for the placement of fourth-year students also called for innovative thinking from the Department. At the beginning of 2009 the Department of Social Work, under the leadership of Professor Rinie Schenck, started with a project called the "Bright Site of Sunnyside". This project developed into a service learning site for fourth-year Social Work students, where they have the opportunity to conduct their practical work under the supervision of supervisors and they can also conduct their research projects in Sunnyside. It also serves as a centre delivering services to the community with the involvement of other departments at UNISA. This service learning site has expanded from accommodating 9 learners in 2009 to 25 in 2010 and 50 learners in 2011.

It is envisaged that the Department will expand this project to other major centres in South Africa and that these projects will be registered as non-profit organisations, from where we shall be able to supervise the practical work of the fourth-year learners and render greater social work service to the community. The ground work for such a project in Durban is already well on its way.

\section{RECOMMENDATIONS}

The Department of Social Work at UNISA is facing challenges related to the increase in student numbers; the reality of limited human resources (supervisors) to teach PCA skills to the social work students; limited physical resources to accommodate the large student numbers; and the limitations in the placement of fourth-year learners for practical work. Taking into consideration the commitment of UNISA to be the African University in the service of humanity and open distance learning, the following recommendations are made:

- The expansion of the "Bright Site" projects to all provinces in South Africa, especially provinces such as the Northern Cape, Mpumalanga and Limpopo, where there is a general lack of resources and learners often move to Gauteng to complete their fourth year of study;

- The maximum use of video-conference facilities (when upgraded by UNISA) to teach PCA skills to social work learners at second- and third-year level; 
- The development of a Postgraduate Certificate of Social Work focusing on PCA. This will increase the human capacity of supervisors for UNISA and enable any social worker to upgrade his/her counselling skills.

\section{CONCLUSION}

The Department of Social Work at UNISA introduces learners to various approaches to counselling in social work. However, our training focuses specifically on teaching learners the theory and practice of person-centred counselling in social work. From this discussion it is clear that the Department of Social Work has experienced numerous challenges in the management of the practical teaching of its learners. We have to ensure that learners understand the theory of person-centred counselling and are competent in applying the skills before they are exposed to working with clients in their final year of study. Although they are supervised by an experienced social worker, and are monitored by another social worker who acts as a contact person in the organisation, it is still the responsibility of the Department of Social Work at UNISA to ensure that we place competent learners with these organisations, and that they adhere to the ethics, norms and standards for student social workers as prescribed by the South African Council for Social Service Professions.

The aim of the current re-curriculation process is to enhance the theoretical and practical competency levels of learners at the end of their third year of study, which will enable us to deliver even more competent learners to the final year of study and improve the quality and quantity of social workers entering practice. However, with an average pass rate of $75 \%$ in 2007; 82\% in 2008 and 77\% in 2009 (UNISA Examinations, 2009) and the reality that the Department of Social Work at UNISA delivers about $70 \%$ of the social workers practising in South Africa (Schenck, 2008), somewhere UNISA must be doing something right!

\section{REFERENCES}

BABBIE, E. \& MOUTON, J. 2002. The practice of social research. New York: Oxford University Press.

BOTHA, P. 2009. Dates and venues for workshops and practice sessions; assignment dates. Tutorial letter 301/2009 for SCK4009. Pretoria: University of South Africa.

BUTHELEZI, R.T. 2002. Social group work with adults: integrating theory and practice. Only study guide for SCK404D. Pretoria: University of South Africa.

DE KOCK, D. 2009. Curriculum, tutorial matter, assignments and practica. Tutorial letter 101/2009 for SCK2024. Pretoria: University of South Africa.

DE KOCK, D. 2010. Workbook to facilitating communication in groups and communities. Tutorial Letter 501/2010 for SCK2024. Pretoria: University of South Africa.

DU PLESSIS, C. \& LOUW, H. 2009. Guide for community work workshops and practicals. Tutorial letter 501/2009 for SCK406F. Pretoria: University of South Africa.

GROBLER, H. 2008a. Theory, values and skills for work with groups and families. Tutorial letter 501/2009 for SCK3028. Pretoria: University of South Africa.

GROBLER, H. 2008b. Guidelines for practical casework, group and family work. Tutorial letter 501/2009 for SCK304A. Pretoria: University of South Africa.

GROBLER, H. 2009a. Social casework. Only study guide for SCK3016. Pretoria: University of South Africa. 
GROBLER, H. 2009b. Dates for workshops, practice and group supervision sessions. Tutorial Letter 102/2009 for SCK304A \& SCK305B. Pretoria: University of South Africa.

GROBLER, H. \& SCHENCK, R. 2009. Person-centred facilitation: process, theory and practice $\left(3^{\text {rd }} \mathrm{ed}\right)$. Cape Town: Oxford University Press Southern Africa.

LAWLOR, G.M. 2008. Examining the fit between personal, learning and practical work contexts of students to further practice excellence in Social Work training. Pretoria: University of South Africa. (Dissertation of limited scope for the MA Social Sciences (Mental Health) at the Department of Social Work)

LINTVELT, R.A. 2008. The personal contexts of undergraduate students in Social Work at UNISA. Pretoria: University of South Africa. (Dissertation of limited scope for the MA Social Sciences (Mental Health) at the Department of Social Work)

LOUW, H. \& DICKER, J. 2001. Community work. Only study guide for SCK3039. Pretoria: University of South Africa.

MBEDZI, R.P. 2009a. General information, curriculum, study material, workshop dates and assignment. Tutorial letter 101/2009 for SCK103Y. Pretoria: University of South Africa.

MBEDZI, R.P. 2009b. Assignment 02: practica tasks and workbook. Tutorial letter 102/2009 for SCK103Y. Pretoria: University of South Africa.

MBEDZI, R.P. 2010. Exploring social workers' integration of the Person-Centred Approach into practice within different working contexts. Pretoria: University of South Africa. (Dissertation of limited scope for the MA Social Sciences (Mental Health) at the Department of Social Work)

MOHAPI, B.J. 2009. Manual for practical group work. Tutorial letter 501/2009 for SCK404D. Pretoria: University of South Africa.

MOHAPI, B.J. \& SCHENCK, C.J. 2006a. Facilitating communication with people in groups and communities. Only study guide for SCK2013. Pretoria: University of South Africa.

MOHAPI, B.J. \& SCHENCK, C.J. 2006b. Practical guide to facilitating communication in groups and communities. Only study guide for SCK2024. Pretoria: University of South Africa.

MOSES, J.W. \& KNUTSEN, T.L. 2007. Ways of knowing: competing methodologies in social and political research. New York: Palgrave MacMillan.

PETTY, A. 2006. Marriage guidance: facilitative couples counselling. Only study guide for MGG201W. Pretoria: University of South Africa.

RSA (REPUBLIC OF SOUTH AFRICA). 1997. Ministry of Welfare and Population Development. White Paper for Social Welfare. Notice 1108 of 1997, Government Gazette, vol. 386, No. 18166 of 8 August. Pretoria, Government Printers.

SCHENCK, C.J. 2002. Practical casework: working with individuals and families. Only study guide for SCK402B. Pretoria: University of South Africa.

SCHENCK, C.J. 2008. Should being a South African make social work training different? Towards giving new meaning to the concept "student-centredness". Unpublished inaugural lecture 21/10/2008: Unisa.

SCHENCK, C.J. 2009. Fourth year overview. Tutorial letter 302/2009 for SCK4009. Pretoria: University of South Africa. 
SKHOSANA, R.M. 2009. Guide for practical community work. Tutorial letter 501/2009 for SCK305B. Pretoria: University of South Africa.

SOCIAL WORK. 2010. Welcome to the Department of Social Work. Home page. [Online]

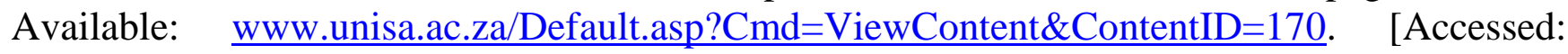
24/09/2010].

STUDENT SYSTEM. 2010. Registrations per subject. [Online] Available: www.unisa. staffonline.ac.za. [Accessed: 03/05/2010].

STUDENT SYSTEM. 2011. Registrations per subject. [Online] Available: www.unisa. staffonline.ac.za. [Accessed: 03/05/2011].

TERRE BLANCHE, M \& DURRHEIM, K. (eds) 2002. Research in practice: applied methods for the social sciences. Cape Town: UCT Press.

UNISA EXAMINATIONS. 2009. Statistical analysis - October/November 2009. Pretoria: Department of Social Work.

UNISA. nd. University of South Africa - the freedom of learning. Pretoria: Studio $M$.

UNISA. nd. 2015 Strategic Plan: an agenda for transformation. [Online] Available: WwW.unisa.staffonline.ac.za. [Accessed: 18/08/2010].

UNISA. nd. Institutional Operational Plan 2010. [Online] Available: www.unisa. staffonline.ac.za. [Accessed: 18/08/2010].

UNISA. 2010. Diversity of learners. [Online] Available: www.unisa.ac.za. [Accessed: 25/08/2010).

UNISA. 2005. Tuition Policy. [Online] Available: www.unisa.staffonline policies. [Accessed: 11/09/2010].

UNISA. 2008. UNISA Open Distance Learning Policy. [Online] Available: WWW.unisa.staffonline policies. [Accessed: 11/08/2010].

VAN DYK, A.C. 2000. Introduction to social work and the helping process. Only study guide for SCK102X. Pretoria: University of South Africa.

VAN DYK, A.C. 2006. Welfare policy. Only study guide for SCK101W. Pretoria: University of South Africa.

VAN DYK, AC \& HARRISON, E. 2008. Social work, supervision and ethics. Only study guide for SCK411C. Pretoria: University of South Africa.

VAN DYK, A.C. 2009. Personal interview - History of the Department of Social Work. 10 May 2009.

WADE, B.L. 2009. UNISA Social Work students' experiences of trauma: and exploratory study from a Person-Centred perspective. Pretoria: University of South Africa. (Thesis submitted for the requirement of the DPhil in Social Work)

ZIMA, P.V. 2007. What is theory? Cultural theory as discourse and dialogue. London: Continuum International Publishing Group.

Prof Desirée de Kock, Department of Social Work, UNISA, Pretoria, South Africa. 